\title{
Situational Precipitators and Interactive Forces in Sexual Crime Events involving Adult Offenders
}

Benoit Leclerc, $\mathrm{PhD}$

School of Criminology and Criminal Justice, Mt Gravatt Campus, Griffith University, Queensland 4111, Australia; phone: +61 (7) 3735 5755; fax: +61 (7) 3735 5608; email: b.leclerc@griffith.edu.au.

Richard Wortley, PhD

Jill Dando Institute of Security and Crime Science, University College London, 35 Tavistock Square, London WC1H 9EZ; phone: +44 (0) 203108 3112; fax: +44 (0) 203108 3088; email: r.wortley@ucl.ac.uk.

Christopher Dowling, PhD Candidate

School of Criminology and Criminal Justice, Mt Gravatt Campus, Griffith University, Queensland 4111, Australia; phone: +61 (7) 3735 3316; email: c.dowling@griffith.edu.au.

Please send correspondence to: Benoit Leclerc, School of Criminology and Criminal Justice, Mt Gravatt Campus, Griffith University, Queensland 4111, Australia; phone: +61 (7) 3735 5755; fax: +61 (7) 3735 5608; email: b.leclerc@griffith.edu.au. 


\section{BIOGRAPHICAL NOTES}

Dr Benoit Leclerc is Associate Professor of Criminology and Criminal Justice at Griffith University, Brisbane, Australia. His research interests include the application and development of crime script analysis for purposes of situational prevention as well as sexual offending. He is the lead investigator of 'What works, what doesn't, and what is promising for preventing sexual violence and abuse: The effectiveness of situational prevention' - project funded by the Australian Research Council.

\section{Prof Richard Wortley}

Professor Richard Wortley is Director of the UCL Jill Dando Institute of Security and Crime Science. His research interests centre on the role that immediate environments play in criminal and corrupt behaviour, and the implications this has for situational crime prevention. He has undertaken funded research in areas including official misconduct in prison, whistleblowing in the public sector, child sexual abuse, Internet child exploitation, and intimate partner homicide.

\section{Christopher Dowling}

Christopher Dowling is a $\mathrm{PhD}$ student with the School of Criminology and Criminal Justice at Griffith University, Brisbane, Australia. His research focuses on the situational context of sexual offending, and the role it plays in the commission of sexual offences. He is currently completing his doctoral thesis on the onset sexual offense of male adolescent sexual offenders. 


\begin{abstract}
We investigated the role of situational precipitators in sexual offenses in relation to the use of physical force by offenders, penetration of the victim and physical injuries to the victim. We used self-report data obtained from a Canadian sample of 553 incarcerated adult male sexual offenders. All data used in this study were gathered through a semi-structured interview conducted with each participant. First, we found that $75.8 \%$ of sexual crime events were somehow precipitated, or characterized by the presence of precipitators before crime. Second, the relationship between each precipitator and the type of offense was statistically significant except for one precipitator. Third, although a number of precipitators were associated with the dependent variables, we also found two interaction effects that illuminated the complexity of the role of precipitators in sexual offenses. Interaction analysis can illuminate our understanding of sexual crime events and better inform prevention practices, such as relapse prevention.
\end{abstract}

Keywords: situational precipitator, sexual offense, sexual offending, interaction effects, severity of offense 


\section{INTRODUCTION}

The immediate environment in which crime is committed is not a passive backdrop to events, but actively shapes the offender's behaviors (Luckenbill, 1977; 1980). This explanation of human behavior has its theoretical roots in psychology (Mischel, 1968), but has also long been supported by work conducted by criminologists in crime prevention (see Clarke, 1967). From the application of this framework two important weaknesses can be identified in the field of sexual offending. First, even though the role of situations has long been recognized in theories of sexual offending (e.g., Finkelhor, 1984; Marshall \& Barbaree, 1990), there has been limited investigation of how situational factors may impact on the severity of sexual offenses. Second, how these factors during sexual crime events interact to generate particular outcomes is not well understood (e.g., Leclerc, Proulx, Lussier \& Allaire, 2009; Mieczkowski \& Beauregard, 2010).

In this study, we examine the role of situations in sexual crime events. , but rather than examining situational factors as causes of sexual offending (e.g., Finkelhor, 1984; Marshall \& Barbaree, 1990), we analyze how these factors influence the severity of sexual offending. Specifically, we focus on the contribution of situational precipitators. In this endeavor, we investigate interactive effects in order to examine the complexity of situational effects and identify the specific circumstances in which they operate. A more detailed knowledge of role of situational precipitators in sexual offending will better inform prevention practices such as relapse prevention. 


\section{THEORETICAL FRAMEWORK}

\section{SITUATIONAL PRECIPITATORS}

Wortley (2001) argues that the immediate environment can precipitate (encourage or induce) individuals to commit crimes that they were not initially contemplating at that time, or escalate the severity of an already contemplated crime. Wortley identifies four types of precipitators generated by the environment, namely, prompts, pressures, permissions and provocations. First, individuals can be prompted to commit crime when thoughts and feelings that would not have had emerged in other situations are brought to the surface by cues in the immediate environment (e.g., feelings of aggression primed by the sight of a weapon). Second, individuals can be pressured to offend through their social affiliations and obligations (e.g., conforming to peer pressure). Third, individuals are 'permitted' to engage in normally proscribed behavior when their moral prohibitions have been weakened (e.g., blaming alcohol for violent altercations). Fourth, individuals can be provoked to engage in criminal behavior under very stressful conditions (e.g., road rage due to frustration). Situational precipitators can provide or increase the motivation to offend and, to the extent that they impact on an individual's emotional state, interfere with the ability to contemplate rational alternative courses of action. This perspective is complementary to the view that the environment can also provide criminal opportunities to potential offenders (Cornish \& Clarke, 2008). 


\section{SITUATIONAL PRECIPITATORS AND THE SEVERITY OF SEXUAL CRIME EVENTS}

The use of alcohol, drugs and pornography. Despite the importance of understanding the use of alcohol, drugs and pornography in sexual offending, very little is known empirically about the contribution of these factors as predictors of the severity of sexual crime events. Ullman (2007) reported that alcohol's role in sexual offenses against women is unclear, but that alcohol is common and is involved in one-half to two-thirds of these offenses. She also noted that offender drinking is often associated with penetration or physical injuries. One hypothesis put forward to explain this association is that alcohol may decrease men's inhibitions against using violence, and this in turn may increase the risk of penetration and physical injuries. This hypothesis is consistent with the explanation provided by Marshall and Barbaree (1990) that alcohol and drugs may lead some offenders to ignore social inhibitions. Ullman also points out to the need for more research on the contribution of alcohol in sexual offenses against women.

On the role of pornography, Marshall (1988) indicated that around $35 \%$ of sexual offenders against either children or women reported that exposure to pornography immediately prior to offending prompted them to sexually offend on at least one occasion. Similarly, Marshall, Seidman and Barbaree (1991) found that prior exposure in a laboratory to images of consensual adult sex elicited the same sexual response from male non-offenders as did images portraying adult sex involving the use of force.

Using a similar mixed sample of sexual offenders as the one used in the current study, Mieczkowski and Beauregard (2010) found that the use of drugs was positively associated with lethality. However, they also noted that drug and pornography use were of little importance in 
predicting lethality compared to victim characteristics. On the other hand, Ouimet, Guay and Proulx (2000) focused on sexual offenses against women specifically and found that the use of alcohol - not the use of drugs - was positively associated with physical injuries.

Balemba and Beauregard (2012) examined sexual crime events committed by a mixed sample of adult offenders and found an interaction effect indicating that when the offender had used alcohol/drugs before the offense, the level of violence in response to victim resistance was lower than when there was no use of alcohol/drugs. Using the same sample, Beauregard and Mieczkowski (2012) indicated that some of the most dangerous combinations involved victim intoxication to alcohol and drugs. For instance, the absence of sexual contact in combination with victim intoxication was likely to result in the death of the victim (for models specific to sexual homicide, see Chan, 2015).

Hamdi and Knight (2012) examined the association between alcohol and drugs and the use of violence, comparing the relationship for offenders against children with offenders against women. Hamdi and Knight found similar levels of positive association between alcohol use and violence for the two groups of offenders. On the other hand, they found that drug use was associated with an increase of violence for offenders against children, but not for offenders against women, a finding that is somewhat inconsistent with that of Ouimet et al. (2000).

Deviant sexual fantasies and sexual excitation. The presence of deviant sexual fantasies and sexual excitation are factors commonly investigated in the field of sexual offending. The importance of understanding the role of these factors in the offending process for relapse prevention or other treatment purposes has been shown previously (e.g., Pithers, Marques, Gibat \& Marlatt, 1983; Proulx, McKibben \& Lusignan, 1996; Ward, Louden, Hudson 
and Marshall, 1995). In addition, these factors have been integrated as key elements in several theoretical explanations of sexual offending (Finkelhor, 1984; Hall \& Hirschman, 1991; 1992; Marshall \& Barbaree, 1990). According to this literature, these factors are believed to precipitate or trigger sexual offenses. However, detailed understanding of the role these factors play in precipitating and intensifying the severity of sexual offending is limited. Nonetheless, using a restricted sample of sexual offenders against children, Leclerc and colleagues found that the presence of deviant sexual fantasies was more likely to characterize offenses committed through manipulation as opposed to coercion or non-persuasive strategies (Leclerc, Carpentier \& Proulx, 2006). In a subsequent study, Leclerc et al. (2009) also found that the presence of deviant sexual fantasies was positively associated with the occurrence of penetration.

Sexual excitation, in particular, has been shown to have a substantial impact on decisionmaking, making individuals more prone to engage in forceful sexual behaviors (Ariely \& Lowenstein, 2006; Lowenstein, Nagin \& Paternoster, 1997). Ariely and Lowenstein (2006), for instance, found that male college students were twice as likely to report that they could imagine being attracted to female children when sexually aroused. In regards to convicted sexual offenders against children, Wortley and Smallbone (2014) recently reported that most offenders indicated being sexually excited before the offense. In addition, a positive association was found between sexual excitation and penetration. Their findings also suggested that offenders who had made a decision to sexually abuse a child became more sexually excited as the moment of abuse approached. However, offenders who acted impulsively did not report higher levels of sexual excitation than offenders who planned their offense. 


\section{CURRENT STUDY}

Situational precipitators are said to encourage or induce the commission of a crime. In other words, all else being equal, an individual who was not planning to commit crime at a particular place and time could be tempted or encouraged to do so under specific circumstances. Accordingly, the use of alcohol, drugs and pornography, the presence of deviant sexual fantasies, and sexual excitation can be viewed as factors likely to precipitate a potential offender in committing a sexual offense. Most importantly, based on previous empirical studies, these factors may also have an impact on the severity of sexual crime events either individually or in interaction. In this study, we are interested in answering the following questions:

1- Are situational precipitators common in sexual offenses? Based on the literature reviewed above, we hypothesize that situational precipitators are common in sexual offenses even though we are unsure to which extent this is the case;

2- What is the contribution of situational precipitators relative to offense type? We hypothesize that situational precipitators vary according to offense type (i.e., child, adolescent or adult victim). This hypothesis is based on recent studies indicating that each type of offense involves a different situation and different offending strategies (e.g., Beauregard, Leclerc \& Lussier, 2012); 3- What is the impact of situational precipitators on the severity of sexual offenses? We hypothesize that situational precipitators will lead to a more severe sexual offense overall. This hypothesis is based on previous literature indicating for instance that the use of alcohol involves the use of more violence from the offender (see literature above). 
4- Are there any interaction effects between situational precipitators and other situational factors on the severity of sexual offenses? The literature is too scarce to formulate any hypothesis about which features may interact and, to which extent, they may do so. This part of the analysis is rather exploratory and we do not make any prediction about what to expect for this particular analysis.

\section{METHOD}

\section{SAMPLE}

The sample consisted of 553 adult males who had been convicted of a sexual offense. These participants were assessed between 1995-2000 at the Regional Reception Centre of SteAnne-des-Plaines, Québec, a maximum-security institution of the Correctional Service of Canada where they underwent a six-week assessment of risk level and treatment needs prior to transfer to another institution. During this assessment, a semi-structured interview was also completed with each participant for research purposes. The research protocols were conducted according to the ethical guidelines stipulated by the Research Ethics Board of the Université de Montréal during the time period in which the participants were interviewed. The majority of participants were Caucasian (82.7\%) and most had less than a high school education (89\%). A total of $51.2 \%$ of participants were single at the time of the crime and only $29.8 \%$ were employed. The average age of participants at the time of assessment was 32 years old $(\mathrm{SD}=8.52)$.

\section{PROCEDURE}

All data used in this study were gathered through a semi-structured interview conducted with each participant using the QIDS (Questionnaire Informatise pour Delinquants Sexuels/Computerized Questionnaire for Sexual Offenders) (St-Yves, Proulx, \& McKibben, 1994), which is a computerized questionnaire for sexual offenders. All interviewers were 
licensed forensic psychologists or criminologists. Participants granted access to their correctional files; official sources of information (e.g., police reports, victim statements, etc.) were also used to validate information, when possible, obtained in the interview. In case of disagreement between both sources, official data were prioritized. The quality of data collected from the QIDS was controlled by completing interrater agreement. Interrater agreement was measured on the basis of 16 interviews conducted jointly by two raters (the principal research assistant and the first author). Ratings were performed independently after these interviews, which were conducted by one interviewer in the presence of the other. The mean kappa was .87 , which represents strong agreement.

The participation in this study was strictly voluntary. Each participant was given an information sheet explaining the research project, its purpose and benefits for research, its potential consequences (e.g., emotional stress) on participants, and the contact details of the chief investigators. Each participant signed a consent form, which stated that the information would be used for research purposes only. No incentives was used.

To avoid limitations related to poor memory recall, only the last victim for which participants were convicted was considered. Still, several events may have occurred between an offender and the victim. Sexual offenses against children often involves a number of incidents over a period of time. Therefore, variables used in this study refer to all events that may have happened with a single victim.

\section{VARIABLES USED IN THE CURRENT STUDY}

The independent variables used in this study consisted of a number of factors that could be defined as situational precipitators for sexual offenses. Specifically, offenders were asked 
whether they used alcohol, drugs and/or pornography before crime. They were also asked whether they had nonspecific sexual deviant fantasies 48 hours before crime and/or sexual deviant fantasies 48 hours before crime, but towards the victim they abuse specifically. In addition, offenders were asked whether they were sexually excited before committing their offense. All these variables were dichotomous $(0=$ absence, $1=$ presence $)$. The statistics for these variables are presented when examining the first research question below.

Our nominated situational precipitators are of two sorts. Half refer to tangible situational elements (alcohol, drugs and pornography) assumed to alter the psychological state of the offender by increasing motivation and/or reducing inhibition; and the other half refer directly to psychological states experienced by the offender just prior the time of the offense (victimspecific sexual fantasies, general sexually-deviant fantasies, and sexual excitation). While in situational crime prevention situational factors are understood to be features of the physical or social environment, in the sex offending literature it has been common to interpret situational influences in terms of transient moods (Amick \& Calhoun, 1987; Marshall \& Barbaree, 1990). It is assumed that these psychological states are in turn elicited or heightened by the presence of specific environmental stimuli, although we do not examine what prompted offenders to have sexual fantasies or experience sexual arousal at that particular time.

\section{ANALYTICAL STRATEGY}

First, we start our analysis by looking at how common are situational precipitators in sexual offenses. Second, we examine the contribution of precipitators relative to offense type. Third, we perform a series of logistic regression to investigate the impact of precipitators on the severity of sexual offenses without testing for interaction effects. Finally, we repeat our logistic regression analyses, but this time we examine the presence of interaction effects. 
As part of logistic regression analyses, three independent variables were used as control variables. First, a variable measuring whether offenders perceived the risk of being apprehended to be high when they committed the abuse was included ( $0=$ low, $1=$ high). We included this variable because one could assume that the impact of precipitators on the severity of the offense will disappear or diminish when the risk of apprehension are high. For instance, an offender who may be encouraged to commit a sexual offense by watching pornography may not perform penetration if he perceives the risk of apprehension to be high. Second, a variable indicating the type of offense committed was included. This variable measured whether the offense was committed against a child, and adolescent or an adult victim $(0=0-12$ years old, $1=13-15$ years old, $2=16$ years old + ). All the adult victims were women. We controlled for the type of offense because, as we will show, the presence of situational precipitators for an offense varies according to this variable. Third, a variable indicating the context of abuse was included as measured by the offender-victim relationship $(0=$ stranger, $1=$ non stranger $)$. We controlled for the context of abuse because stranger offenses are more likely to lead to serious harm, including physical injury to (Ullman \& Siegel, 1993) and death of (Mieczkowski \& Beauregard, 2010) the victim.

In order to examine the third and fourth research questions through logistic regression analyses, three dependent variables for measuring the severity of the offense were included. The first variable was the use of physical force to commit the offense, the second the performance of penile penetration on the victim (vaginal and/or anal), and the third the infliction of physical injuries to the victim. These variables were all dichotomous $(0=$ absence, $1=$ presence $)$. The statistics for these variables are presented when examining the second and third research questions below. 


\section{RESULTS}

\section{ARE SITUATIONAL PRECIPITATORS COMMON IN SEXUAL OFFENSES?}

As depicted in Table 1, the most common precipitator in sexual crime events was the use of alcohol. A total of $43.2 \%$ of offenders used alcohol before crime. The use of drugs, the presence of deviant sexual fantasies towards the victim, or not, were also fairly common precipitators of sexual crime events $(26.3 \%, 25.5 \%, 22.1 \%$, respectively). On the other hand, few offenders used pornography $(14 \%)$ or were sexually excited before the offense $(12.4 \%)$. Interestingly, when computing all the precipitators above, we found that $75.8 \%$ of sexual crime events were precipitated, or at the least, characterized by the presence of precipitators before the offense.

INSERT TABLE 1

\section{WHAT IS THE CONTRI, BUTION OF SITUATIONAL PRECIPITATORS RELATIVE TO THE TYPE OF SEXUAL OFFENSE?}

In Table 2, we examine whether or not the presence of precipitators in sexual crime events fluctuates according to the type of offense, or more specifically, as a function of the type of victim abused during the offense (child, adolescent or adult woman). In this sample, the proportions of sexual offenses committed against children, adolescent and adult women were, respectively, $47.8 \%, 15.6 \%$, and $36.6 \%$. A series of chi-square tests was performed to examine the relationships between the precipitators.

There were statistically significant relationships between each precipitator and the type of offense. The use of alcohol before the offense was more frequent in sexual offenses committed against adult women than in sexual offenses committed against adolescent victims or children. 
The use of drugs was significantly less frequent in sexual offenses committed against children than in other offenses. In addition, the use of pornography and the presence of deviant sexual fantasies towards the victim (and non-specific fantasies) were less frequent in sexual offenses committed against adult women than in other offenses. Similarly, sexual offenders against women were less likely to be sexually excited before crime than sexual offenders against adolescent victims or children.

INSERT TABLE 2

\section{WHAT IS THE IMPACT OF SITUATIONAL PRECIPITATORS ON THE SEVERITY OF SEXUAL OFFENSES?}

Tables 3, 4 and 5 examine the predictive power of situational precipitators in relation to the severity of sexual offenses while controlling for the level of risk of apprehension, the context of abuse and the type of sexual offense. In this sample, $38.9 \%$ of offenders reported that the risk of apprehension was high when they committed their offense. In addition, most offenders knew their victim before the offense. The proportion of offenders who knew their victim among offenders against children, adolescents and adults were, respectively, $96.5 \%, 85.7 \%$ and $70.6 \%$. The proportions of offenders who used physical force, performed penetration on the victim and/or inflicted physical injuries to the victim were, respectively, $62.5 \%, 71.6 \%$ and $28.7 \%$.

\section{INSERT TABLES $3,4 \& 5$}

Table 3 presents the results in relation to the use of physical force. Model 1 shows that the use of alcohol before the offense increases the likelihood of using physical force during the offense ( $\Psi=3.166)$. The presence of deviant sexual fantasies about the victim decreases the use of physical force $(\Psi=.243)$. On the other hand, the presence of nonspecific deviant sexual 
fantasies increases the use of physical force $(\Psi=5.199)$. Sexual excitation also decreases the use of physical force $(\Psi=.200)$. The results of models 2,3 and 4 indicate that precipitators are still strongly associated with the use of physical force. Moreover, offenses involving adolescent victims or adult women are more likely to involve the use of physical force than offenses committed against children.

Table 4 shows the results of the analysis conducted on penetration of the victim. Model 1 indicates that the use of alcohol increases the likelihood of penetration, but this effect disappears when introducing the type of offense in model 3 . In the end, the use of pornography and the presence of nonspecific deviant sexual fantasies decrease the likelihood of penetration $(\Psi=.491$ and .460 , respectively). The type of offense is again strongly associated with penetration.

Table 5 presents the results in relation to the infliction of physical injuries to the victim during the offense. Model 1 indicates that the use of alcohol or drugs before the offense increases the likelihood of physical injuries ( $\Psi=2.955,1.872$, respectively). On the other hand, the use of pornography, the presence of deviant sexual fantasies towards the victim and sexual excitation decrease the likelihood of physical injuries ( $\Psi=.420, .320, .138$, respectively). In model 2 , these relationships remain significant despite the fact that the variable of risk of apprehension is also significant. From model 3 to model 4, a number of effects disappear. In the end, the use of alcohol, sexual excitation and the type of offense are significantly related to physical injuries. In regards to the later, offenses committed against adult women are more likely to involve physical injuries than offenses committed against children. 


\section{IS THERE ANY INTERACTION EFFECTS BETWEEN SITUATIONAL PRECIPITATORS AND OTHER SITUATIONAL FACTORS ON THE SEVERITY OF SEXUAL OFFENSES?}

The fourth research question investigates whether interaction effects emerge between situational precipitators and other situational characteristics (see Table 6). Our findings that sexually-related precipitators (sexual excitation, general and specific sexual deviant fantasies, and the use of pornography) were in several cases negatively related to offense severity variables (physical force, penetration and physical injuries) were contrary to the literature. In light of these findings, the investigation of interaction effects focused on sexually-related precipitators. Table 6 only include the two interaction effects that were found to be significant during the analysis. First, we found that when the offender is sexually excited before the offense, he is more likely to use physical force to commit the offense when the victim is a stranger, but less likely to do so when the victim is known to him. Second, we found that when the risks of apprehension are high, the offender is more likely to perform penetration when he does not have deviant sexual fantasies, but less likely to do so when he does have these fantasies.

\section{INSERT TABLE 6}

Note that the introduction of these interaction terms also affected some of the main effects; the main effect of sexual excitation on the use of physical force (model 1) and physical injuries (model 3), the main effect of general deviant fantasies on penetration (model 2), and the main effect of pornography use on penetration (model 2) disappear. The remaining sexuallyrelated main effects were the negative association between specific sexual fantasies and use of force and the positive association between general sexual fantasies and use of force (model 1). 


\section{DISCUSSION}

\section{THE ROLE OF SITUATIONAL PRECIPITATORS IN SEXUAL CRME EVENTS}

We set out to answer three questions concerning the role of situational precipitators in sexual offending. The first question concerned the extent to which crime precipitators were present in sexual offenses. We found that three-quarters of the sample acknowledged the presence of at least one of these factors, the most commonly reported being the consumption of alcohol, which provides support to the first hypothesis. We acknowledge, of course, that identifying the presence of precipitators is not necessarily the same as showing that they played a causative role in the occurrence of the offense. Nonetheless, what this finding means is that a large number of sexual offenses are somehow associated with events (e.g., drinking or using drugs) and states (e.g., fantasies) plausibly implicated in prompting offenders to sexually offend.

Perhaps the most puzzling of the current findings is the large proportion of offenders $(87.6 \%)$ who claimed not to have been sexually excited before the offense. Wortley and Smallbone (2014) also found for their sample of child sex offenders that many offenders (though fewer $-37 \%$ - than in the current study) similarly reported not being sexually excited just prior to their offense. These findings beg the question of why, in the absence of sexually excitation before the offense, offenders proceed with the offense. There are three possible explanations. The first is that the offenders are not being truthful, either as an act of deliberate deception or through a process of psychological denial. They may deny feelings of sexual excitation in order to project a good impression to others or to assuage their own feelings of guilt, perhaps as part of a wider syndrome of cognitive distortion around their offending, often thought typical of sex offenders (e.g., Ward et al., 1997). The second explanation is that the offenders are being truthful and that their offenses were not precipitated by sexual excitation. Their offending may have 
occurred spontaneously as a sudden impulse, or they may have been motivated by the need to express power and dominance (e.g., Zurbriggen \& Yost, 2004), or to find intimacy (McKillop et al, 2012). Some or all of these offenders may have become sexually excited, but only after they had initiated the offense. The third explanation is that the offenders do not know what role their affective state played in their offense. Self-report methods such as those used in the current study assume that individuals are capable of meaningful introspection about the causes of their behavior. This assumption, however, is questionable for people generally (Greenwald \& Banaji, 1995) including sex offenders (Dawson et al., 2009; Laws \& Marshall, 2003). Offenders may be genuinely puzzled by the emotional origins of their own offending, and we may have asked them to perform a difficult task to carry out.

The second research question of the current study concerned possible variations in the role of crime precipitators among offense types. Consistent with the second hypothesis, we found considerable variation across offense types. Offenders against children were the most likely to have victim-specific fantasies, but the least likely to have used alcohol or drugs; offenders against adolescents were the most likely to have used pornography; and offenders against adults were the most likely to have used alcohol and drugs, but the least likely to have used pornography, to have victim-specific fantasies and to become sexually excited. These patterns are consistent with the routine activities of the respective groups. Offenders against children were the most likely to have known their victim and thus to have had had the most opportunity to develop specific sexual fantasies about them (96.5\%). Offending against children also often occurs during care-giving activities such as bathing the child (Wortley \& Smallbone, 2006), while offending against adults often occurs in the context of social activities (e.g., so-called date rapes; Anglin et al, 1997). Perpetrators of sexual offenses against adults, then, may be more 
likely to encounter the victim under circumstances where alcohol and drugs are being consumed, a scenario which is consistent with the literature showing that alcohol use is involved in up to half or two thirds of all sexual offenses (Ullman, 2007). This explanation may be plausible for offenders against adolescents as well regarding the use of pornography (note that these offenders were also more likely to use alcohol and drugs than offenders against children). In addition, offenders against adolescents may use alcohol, drugs and pornography in order to desensibilize their victims to sexual activity, which would be consistent with the discovery period of adolescence.

The third question of this study concerns the effect of crime precipitators on the nature and outcome of offending. Our findings were mixed, which indicates that the third hypothesis is partially supported. In the full models (controlling for risk of apprehension, context of abuse and offense-type) the use of physical force was associated with increased alcohol use and general sexual fantasies, but with decreased victim-specific sexual fantasies and sexual excitation; penetration was associated with decreased non-specific sexually-deviant fantasies and use of pornography; and injuries to the victim was associated with increased alcohol use, but with decreased sexual excitation. Consistent with the literature, alcohol use was associated with increased offending severity, specifically in the cases of the use of force (see also Ullman, Karabatsos \& Koss, 1999) and injury to the victim (see also Martin \& Bachman, 1998; Ouimet et al., 2000). General sexually-deviant fantasies were associated with increased use of force, but with decreased penetration. Specific sexual fantasies (in the case of use of force), pornography (in the case of penetration) and sexual excitation (in the cases of use of force, penetration and injury) were associated only with decreased severity. 
Seemingly the most anomalous of these findings was the association between sexual excitation and decreased offending severity. Ariely and Lowenstein (2006) found precisely the opposite pattern with college students. When the participants in their study became sexually excited their preparedness to be forceful and to take risks in their pursuit of sexual gratification increased significantly. Similarly, Wortley and Smallbone (2014) found that child sexual offenders who indicated that they were sexually excited at the time of their offense were more likely to perform more serious sexual acts, including penetration, on their victim.

The fourth research question on interaction effects offers a key into disentangling the findings obtained to answer the third research question. The first interactive effect between sexual excitation and the context of abuse neutralized the anomalous negative association between sexual excitation and physical force and physical injuries, which provided some critical insights for solving the apparent discrepancy. In fact, in the case of physical force, at least, sexual excitation is associated with increased use only for victims who are strangers, while introduction of the interaction term into the models also causes the negative main effects for physical force and injury to disappear. This finding suggests that the role of excitation must be understood within the broader context of the pre-existing social relationship between the offender and the victim. We can hypothesize that when the offender already knows the victim he is able to exploit an established relationship with the victim to gain co-operation. Only when the victim is a stranger does it become necessary for the offenders to utilize force, and the preparedness to do so increases with his state of sexual excitation. This finding is consistent with a typology of sexual offenders against women developed by Knight and Prentky (1990) decades ago. In fact, Knight and Prentky identified a group of sexual offenders who are characterized by long-term planning and a fusion of sexuality and violence displayed against stranger victims. 
Although the empirical link between stranger offending and the use of force and violence is established in the literature (e.g., Ullman \& Siegel, 1993), there is insufficient research on the role of sexual arousal to allow any firm conclusions to be drawn about the current findings.

The other interaction effect also enhances our understanding of sexual offending. Penetration was associated with the presence of general sexually-deviant fantasies in combination with low risk of apprehension. Again this interactive effect overrides the initial and unexpected negative association between general fantasies and penetration - it disappeared. One possibility to explain this finding is that general sexually-deviant fantasies before the offense are indicative of a sexual deviant lifestyle and dispositional deviance and so are also associated with longer term planning. Those offenders who are dispositionally deviant are more likely to engineer low risk encounters with potential victims; offenders who are not dispositionally deviant are more likely to offend opportunistically, including in circumstances of relatively high risk. This hypothesis makes sense in light of the most recent evidence on pathways to sexual aggression (Proulx, Beauregard, Lussier \& Leclerc, 2014). This body of work indicates that child sexual offenders as well as extrafamilial sexual offenders against women who carefully plan their offenses are more likely to have a sexual deviant lifestyle, which is characterized by the presence of general deviant sexual fantasies in everyday life.

The remaining sexually-related main effects are the negative association between specific sexual fantasies about the victim and the use of force, and the positive association between general sexually deviant fantasies and the use of force. Again, on the face of it these findings seem contradictory, but pursuing the arguments raised above, they too would be related to the sexual orientation of the offender. Those offenders with general sexually-deviant fantasies may be the most determined and so the most willing to force sexual contact in the face of victim 
resistance. On the other hand, those offenders who have specific sexual fantasies about the victim may be more interested in forming an emotional relationship with the victim, and so be more likely to use non-forceful strategies to gain victim compliance.

At a broader theoretical level, the presence of interactive effects between different situational factors and/or precipitators in sexual crime events is consistent with the precipitators' framework conceptualised by Wortley (2001). The core idea of this framework is that the environment can create or intensify the motivation to offend as well as provide the opportunity to do so. Situational precipitators such as alcohol, drugs, fantasies and sexual excitation should be expected to interact with other situational factors in generating the decision to commit the crime itself. This perspective is also consistent with violent offenders' decision-making process during crime (Felson, 2013). Felson (2013) makes a convincing case that violent crimes such as sexual offenses against women involve instrumental aggression resulting from ill-considered decisions generated by situational factors such as alcohol intoxication or particular affective states. In this study, we have observed that the emergence of a particular crime event outcome may be dependent upon psychological states experienced by the offender (e.g., fantasies, sexual excitation) in conjunction with other situational factors in the immediate environment such as the context of abuse and the risk of being apprehended. Therefore, not only may interactions between the psychological states of the offender and situational factors lead to the decision to commit a crime as explained by Wortley, but they may also prove to be key factors in explaining crime event outcomes. Precipitators not only precipitate the decision to commit crime, but contribute to the explanation of crime event outcomes in conjunction with other situational factors. From this perspective, it can be argued that overlooking the role of precipitators in sexual crime events may be detrimental to an accurate understanding of sexual offenses. 


\section{SITUATIONAL PRECIPITATORS AND RELAPSE PREVENTION}

In the field of sexual offending, Pithers et al. (1983) borrowed Marlatt's conceptualization of the relapse process for individuals with an addiction and adapted it to the treatment of sexual offenders (Marlatt \& Gordon, 1980). Initially, the relapse prevention model contained three stages. Ward et al. (1995) then generated a complete model based on their work on the offending process of child sex offenders. Another version, the self-regulation model, was also developed by these researchers (Ward, Polaschek \& Beech, 2006). Regardless of the specificity of the model used, this work highlighted the importance that factors, such as alcohol use, sexual arousal and deviant sexual fantasies, played in sexual reoffending.

One significant value of the relapse prevention model is the recognition of the role of precipitators such as alcohol and deviant sexual fantasies in sexual offending under a particular set of circumstances pertinent to each offender. The underlying idea of the relapse prevention model is to break down the pathway to sexual reoffending into a series of steps, which include cognitive, behavioral and affective components, so that offenders can understand the process leading to their own offending. Through relapse prevention, situational features such as alcohol and deviant sexual fantasies - those that could push an offender over the edge and reoffend - are targeted by clinicians to reduce risks of recidivism. In addition, clinicians can determine the set of particular circumstances under which these situational factors operate to assist offenders from putting themselves in high-risk situations when they are released in the community. This model is essential for clinicians to equip offenders with a set of tools and reminders to help them recognise situations to avoid in the future in order to not reoffend. 
The current study provides further support for the relevance of examining situational precipitators in sexual offenders' treatment settings. In particular, we examined the relationship between those features and the severity of sexual offenses, adding a critical layer to further understand the contribution of situational precipitators to relapse prevention. Indeed, evidencebased knowledge about which precipitators are more likely to be associated with physical force, physical injuries and/or penetration is of value for clinicians as this knowledge can assist them to narrow their focus on situational features that increase the harm done to victims. Most importantly, the current study specifies under which conditions particular precipitators may operate in the escalation to a more severe assault. The first interaction effect indicated that when the offender is sexually excited, he is more likely to use physical force when the victim is a stranger, but less likely to do so when the victim is known to him. This finding suggests that sexual excitation represents a salient risk factor for offenders likely to offend against stranger victims, and that clinicians could pinpoint this context for relapse prevention purposes with stranger offenders in particular. The second interaction effect indicated that penetration is more likely in situations where offenders do not exhibit fantasies, but are likely to get caught. Put another way, this effect indicated that penetration is more likely when offenders have fantasies in a context in which they are unlikely to get apprehended. Regardless of the way this effect is viewed, this finding suggests that clinicians should pay attention to how risks of getting caught interact with deviant sexual fantasies as these two features may represent a dangerous combination for victims, but also another target point for relapse prevention. These two interaction effects can be used as signals of (severe) reoffending. Finally, empirical knowledge on how situational precipitators and other features of the offense interact in reality can best be examined through quantitative not qualitative analysis, which means that there is also a need for 
researchers to render this evidence-based knowledge accessible to clinicians. From this point too, the contribution of this study is stressed for both understanding and preventing sexual offenses.

Similarly, evidence-based knowledge gathered through the investigation of interactive effects can be quite powerful to inform victims on how best to react in situations of sexual victimization. Ullman (2007) pointed out the need to inform adult victims to equip them for selfprotection. However, what we discovered in this study is the complexity of the situation under which sexual offenses are committed. How and by which precipitators the offense is triggered in combination with other situational factors is valuable to depict a portrait of different potential scenarios if possible, but quite difficult to achieve. Then one must also consider the type of offense (or victim), which appears to play a major role in shaping how the offense unfolds. Our conclusion is that this study may only be the tip of the iceberg on interaction effects - thus insufficient to think seriously in terms of victim self-protection recommendations at this stage.

This study has used three dependent variables to tap into the severity of sexual crime event outcomes, that is, the use of force, penetration and physical injuries. As typically seen in the literature, these variables were dichotomous rather than ordinal or continuous. In relation to sexual behaviors specifically, Leclerc and Tremblay (2007) did not use dichotomous measures. They rather created an index to measure the intrusiveness of sexual behaviors performed by the offender during crime. One index was also developed to measure the intrusiveness of sexual behaviors performed by the victim under the coercion or manipulation of the offender. Consistent with our findings, a number of interactive effects were discovered highlighting the role of offending strategies on sexual crime event outcomes and most importantly, the need to examine for the presence of interactive effects in sexual crime events regardless of the type of variable used in the analysis. 


\section{LIMITATIONS}

Like any research, the current study also contains methodological limitations. First, as our sample is composed of incarcerated offenders, our results may also not be representative of all sexual offenses. It may be, for example, that active offenders are less influenced by precipitators than are incarcerated offenders and thus less likely to get caught. Second, the present study is based on self-report data, which means that some findings may be biased by offenders' cognitive distortions. For instance, it is possible that some offenders, in order to present a positive image of themselves, reported that they were not sexually excited before the offense when they were - a sensible topic from the offender's point of view.

\section{CONCLUSIONS}

The current study provides insights into the role of precipitators in sexual offenses. Through the examination of interaction effects, the nature of that role is more complex than we had originally envisaged. In particular, we found that whether sexual fantasies and sexual excitation increase or decrease offending severity may depend upon the context of abuse (nature of offender-victim relationship), and the dispositional deviance of the offender. Beyond its relevance for understanding the role of crime precipitators more generally or how sexual offenses occur specifically, the current study reminds us of the critical need to investigate for the presence of interaction effects both for understanding sexual offending and treating offenders.

Interaction effects made a major contribution into understanding sexual criminal behavior in this study because: 1) their absence in statistical models would have masked crucial relationships that cannot be otherwise uncovered, 2) their presence neutralized some anomalous findings that would have led to an incorrect interpretation of the findings, and 3) they offered a 
more accurate and nuanced account of the complexity of situations that characterizes sexual crime event patterns. However, how to make sense of interactive effects when examining crime events is not a simple task as all the crime components interact in multiple and various ways simultaneously in reality regardless of whether the individual is offending for the first time or reoffending. On this, cognitive psychologists such as Hastie and Dawes (2010) have made the point that humans do not have the cognitive capacity to capture effectively a large amount of information simultaneously on a particular situation and process it in order to come up with accurate judgements. In other words, a researcher or practitioner cannot simply perform the cognitive task of examining how, and to which extent, different factors interact in a situation to produce a particular outcome. Hastie and Dawes demonstrated that the examination of interactive effects through quantitative analysis provides an effective and accurate way to tap into the dynamic nature of situations and human decision making. In this study, interactive effects specified the situations into which precipitators may be related to the severity of sexual crime events. Coupled with qualitative-driven investigations on the rationales underlying the decision to commit a sexual offense (e.g., Beauregard \& Leclerc, 2007), interaction analysis can illuminate our understanding of sexual crime events and better inform prevention practices, such as relapse prevention.

\section{ACKNOWLEDGEMENTS}

We are greatful to Prof Jean Proulx for giving us access to the data used in this study. 


\section{REFERENCES}

Amick, A. E., \& Calhoun, K. S. (1987). Resistance to sexual aggression: Personality, attitudinal, and situational factors. Archives of Sexual Behavior, 16, 153-163.

Anglin, D., Spears, K. L., \& Hutson, H. (1997). Flunitrazepam and its involvement in date or acquaintance rape. Academic emergency medicine, 4, 323-326.

Ariely, D., \& Lowenstein, G. (2006). The heat of the moment: The effect of sexual arousal on sexual decision making. Journal of Behavioral Decision Making, 19, 87-98.

Balemba, S., \& Beauregard, E. (2012). Reactions to resistance: The role of contextual factors in sex offending. Violence and Victims, 27, 148-165.

Beauregard, É., \& Leclerc, B. (2007). An application of the rational choice approach to the offending process of sex offenders: A closer look at the decision-making. Sexual Abuse: A Journal of Research and Treatment, 19, 115-133.

Beauregard, E., Leclerc, B., \& Lussier, P. (2012). Decision-making in the crime-commission process: Comparing rapists, child molesters, and victim-crossover sex offenders. Criminal Justice and Behavior, 39, 1275-1295.

Beauregard, E., \& Mieczkowski, T. (2012). Risks of estimation of the conjunction of victim, crime event characteristics on the lethal outcome of sexual assaults. Violence \& Victims, 27, 470-486.

Chan, H. C. O. (2015). Understanding sexual homicide offenders: An integrated approach. Basingstoke, UK: Palgrave Macmillan.

Clarke, R. V. (1967). Seasonal and other environmental aspects of abscondings by approved school boys. British Journal of Criminology, 7, 195-206. 
Cornish, D. B., \& Clarke, R. V. (2008). The rational choice perspective. In R. Wortley \& L. Mazerolle (Eds.), Environmental criminology and crime analysis (pp. 21-47). Cullompton, UK: Willan.

Dawson, D. L., Barnes-Holmes, D., Gresswell, D., M., Hart, A. J., \& Gore, N. J. (2009). Assessing the implicit beliefs of sexual offenders using the implicit relational assessment procedure. A first study. Sexual Abuse: A Journal of Research and Treatment, 21, 57-75.

Felson, R. B. (2013). What are violent offenders thinking? In B. Leclerc \& R. Wortley (Eds.) Cognition and crime: Offender decision-making and script analyses. Crime Science Series, London, UK: Routledge.

Felson, R. B., Burchfield, K. B., \& Teasdale, B. (2007). The impact of alcohol on different types of violent incidents. Criminal Justice \& Behavior, 34, 1057-1068.

Finkelhor, D. (1984). Child sexual abuse: New theory and research. New York: The Free Press.

Greenwald, A. G., \& Banaji, M. R. (1995). Implicit social cognition: attitudes, self-esteem, and stereotypes. Psychological review, 102, 4-27.

Hall, G. C. N., \& Hirschman, R. (1991). Toward a theory of sexual aggression: A quadripartite model. Journal of Consulting and Clinical Psychology, 59, 662-669.

Hall, G. C. N., \& Hirschman, R. (1992). Sexual aggression against children: A conceptual perspective of etiology. Criminal Justice and Behavior, 19, 8-23. 
Hamdi, K., \& Knight, R. (2012). The relationships of perpetrator and victim substance use to the sexual aggression of rapists and child molesters. Sexual Abuse: A Journal of Research and Treatment, 24, 307-327.

Hastie, R., \& Dawes, R. M. (2010). Rational choice in an uncertain world: The psychology of judgement and decision making ( $2^{\text {nd }}$ edition). Los Angeles, California: Sage Publications.

Knight, R., \& Prentky, R. (1990). Classifying sexual offenders: The development and corroboration of taxonomic models. In W. L. Marshall, D. R. Laws \& H. E. Barbaree (Eds.), The handbook of sexual assault: Issues, theories, and treatment of the offender (pp. 23-52). New York: Plennum.

Laws, D. R., \& Marshall, W. L. (2003). A brief history of behavioral and cognitive behavioral approaches to sexual offenders: Part 1. Early developments. Sexual Abuse: A Journal of Research and Treatment, 15, 75-92.

Leclerc, B., Carpentier, J., \& Proulx, J. (2006). Strategies adopted by sexual offenders to involve children in sexual activity. In R. Wortley \& S. Smallbone (Eds), Crime Prevention Studies: Vol. 19. Situational prevention of child sexual abuse, Monsey, NY: Criminal Justice Press.

Leclerc, B., Proulx, J., Lussier, P., \& Allaire, J-F. (2009). Offender-victim interaction and crime event outcomes: Modus operandi and victim effects on the risk of intrusive sexual offenses against children. Criminology, 47, 595-618.

Leclerc, B., \& Tremblay, P. (2007). Strategic behavior in adolescent sexual offenses against children: Linking modus operandi to sexual behaviors. Sexual Abuse: A Journal of Research and Treatment, 19, 23-41. 
Loewenstein, G., Nagin, D., \& Paternoster, R. (1997). The effect of sexual arousal on expectations of sexual forcefulness. Journal of Research in Crime and Delinquency, 34, 443-473.

Luckenbill, D. F. (1977). Criminal homicide as a situated transaction. Social Problems, 25, 17686.

Luckenbill, D. F. (1980). Patterns of force in robbery. Deviant Behavior, 1, 361-378.

Marlatt, G. A., \& Gordon, J. R. (1980). Determinants of relapse: Implications for the maintenance of change. In P. O. Davidson \& S. M. Davidson (Eds.), Behavioral medicine: Changing health lifestyles (pp. 410-452). New York, NY: Brunner/Mazel.

Marshall, W. L. (1988). The use of sexually explicit stimuli by rapists, child molesters, and nonoffenders. Journal of Sex Research, 25, 267-288.

Marshall, W. L., \& Barbaree, H. E. (1990). An integrated theory of sexual offending. In W. L. Marshall, D. R. Laws \& H. E. Barbaree (Eds.), Handbook of sexual assault: Issues, theories, and treatment of the offender (pp. 257-275). New York: Plenum Press.

Marshall, W. L., Seidman, B. T., \& Barbaree, H. E. (1991). The effects of prior exposure to erotic and nonerotic stimuli on the rape index. Annals of Sex Research, 4, 209-220.

Martin, S., \& Bachman, R. (1998). The contribution of alcohol to the likelihood of completion and severity of injury in rape incidents. Violence Against Women, 4, 694-712.

McKillop, N., Smallbone, S., Wortley, R., \& Andjic, I. (2012). Offenders' attachment and Sexual abuse onset: A test of theoretical propositions. Sexual Abuse: A Journal of Research and Treatment, 24, 591-610. 
Mieczkowski, T., \& Beauregard, E. (2010). Lethal outcome in sexual assault events: A conjunctive analysis. Justice Quarterly, 27, 332-361.

Mischel, W. (1968). Personality and assessment. New York, NY: Wiley.

Ouimet, M., Guay, J. P., \& Proulx, J. (2000). Analyse de la gravite des aggressions sexuelles de femmes adultes et de ses determinants (Analysis of the seriousness of sexual assault of adult women and its determinants). Revue Internationale de Criminologie et de Police Technique et Scientifique, 53, 157-172.

Pithers, W. D., Marques, J. K., Gibat, C. C., \& Marlatt, G. A. (1983). Relapse prevention with sexually aggressive: A self-control model of treatment and the maintenance of change. In J. G. Greer \& I. R. Stuart (Eds.), The sexual aggressor: Current perspectives on treatment (pp. 214-234). New York: Van Nostrand Reinhold.

Proulx, J., Beauregard, E., Lussier, P., \& Leclerc, B. (Eds.) (2014). Pathways to sexual aggression. London, UK: Routledge.

Proulx, J. McKibben, A., \& Lusignan, R. (1996). Relationships between affective components and sexual behaviors in sexual aggressors. Sexual Abuse: A Journal of Research and Treatment, 8, 279-289.

St-Yves, M., Proulx, J., \& McKibben, A. (1994). Questionnaire informatisé sur les délinquants sexuels (Computerized Questionnaire for Sexual Offenders). Unpublished document. Correctional Service of Canada. 
Ullman, S. E. (2007). A 10 -year update of "Review and critique of empirical studies of rape avoidance". Criminal Justice and Behavior, 34, 411-429.

Ullman, S. E., Karabatsos, G., \& Koss, M. P. (1999). Alcohol and sexual assault in a national sample of college women. Journal of Interpersonal Violence, 14, 603-625.

Ullman, S. E., \& Siegel, J. M. (1993). Victim-offender relationship and sexual assault. Violence and Victims, 8, 121-134.

Ward, T., Louden, K., Hudson, S., \& Marshall, W. L. (1995). A descriptive model of the offense chain for child molesters. Journal of Interpersonal Violence, 10, 452-472.

Ward, T., Hudson, S. M., Johnston, L., \& Marshall, W. L. (1997). Cognitive distortions in sex offenders: An integrative review. Clinical Psychology Review, 17, 479-507.

Ward, T., Polaschek, D. L. L., \& Beech, A. R., (2006). Theories of sexual offending. Chichester, England: John Wiley \& Sons.

Wortley, R. (2001). A classification of techniques for controlling situational precipitators of crime. Security Journal, 14, 63-82.

Wortley, R. (2013). Exploring the person-situation interaction in situational crime prevention. In N. Tilley \& G. Farrell (Eds.), The reasoning criminologist: Essays in honour of Ronald V. Clarke. (pp. 184-193). London, UK: Routledge.

Wortley, R., \& Smallbone, S. (2006). Applying situational principles to sexual offenses against children. In R. Wortley \& S. Smallbone (Eds.), Crime prevention studies: Vol. 19. Situational prevention of child sexual abuse (pp. 7-35). Monsey, NY: Criminal Justice Press. 
Wortley, R., \& Smallbone, S. (2014). Emotional arousal and child sex offending: A situational perspective. In J-L. Van Gelder, H. Elffers, D. Nagin \& D. Reynald (Eds.), Affect and Cognition Affect and Cognition in Criminal Decision Making; Between Rational Choices and Lapses of Self-Control (pp. 119-139). London: Routledge.

Zurbriggen, E. L., \& Yost, M. R. (2004). Power, desire, and pleasure in sexual fantasies. Journal of Sex Research, 41, 288-300. 
Table 1. Descriptive Statistics for the Situational Precipitator Variables (\% Yes) $(N=553)$

\begin{tabular}{ll}
\hline Variable & Distributions \\
\hline Used alcohol before crime & 43.2 \\
& Base $n=537$ \\
& 26.3 \\
Used drugs before crime & Base $n=539$ \\
& 14 \\
Used pornography before crime & Base $n=535$ \\
& 25.5 \\
Had deviant sexual fantasies towards victim & Base $n=521$ \\
48 hours before crime & 22.1 \\
Had nonspecific deviant sexual fantasies 48 & Base $n=521$ \\
hours before crime & 12.4 \\
& Base $n=450$ \\
Was sexually excited before crime & 75.8 \\
Any of the precipitators above & Base $n=426$ \\
\hline
\end{tabular}


Table 2. Situational Precipitators by Type of Offense (\% Yes)

\begin{tabular}{|c|c|c|c|c|}
\hline & $\begin{array}{l}\text { Sexual offenses } \\
\text { against a child } \\
(0-12)\end{array}$ & $\begin{array}{l}\text { Sexual offenses } \\
\text { against an } \\
\text { adolescent (13- } \\
\text { 15) }\end{array}$ & $\begin{array}{l}\text { Sexual offenses } \\
\text { against an adult } \\
\text { woman }(16+)\end{array}$ & $\begin{array}{l}\text { Chi-square } \\
\text { Value }\end{array}$ \\
\hline $\begin{array}{l}\text { Used alcohol } \\
\text { before crime*** }\end{array}$ & $28.4 \%$ & $40 \%$ & $62.4 \%$ & 52.432 \\
\hline $\begin{array}{l}\text { Used drugs } \\
\text { before crime*** }\end{array}$ & $13.5 \%$ & $34.9 \%$ & $39 \%$ & 40.446 \\
\hline $\begin{array}{l}\text { Used } \\
\text { pornography } \\
\text { before crime* }\end{array}$ & $15.3 \%$ & $22 \%$ & $8.8 \%$ & 9.102 \\
\hline $\begin{array}{l}\text { Had deviant } \\
\text { sexual fantasies } \\
\text { towards victim } \\
48 \text { hours before } \\
\text { crime*** }\end{array}$ & $34.6 \%$ & $24.7 \%$ & $14.2 \%$ & 23.233 \\
\hline $\begin{array}{l}\text { Had nonspecific } \\
\text { deviant sexual } \\
\text { fantasies } 48 \\
\text { hours before } \\
\text { crime*** }\end{array}$ & $24.6 \%$ & $16.3 \%$ & $19.9 \%$ & 2.947 \\
\hline $\begin{array}{l}\text { Was sexual } \\
\text { excited before } \\
\text { crime* }\end{array}$ & $16.1 \%$ & $16.4 \%$ & $6.6 \%$ & 10.908 \\
\hline
\end{tabular}


Table 3. Logistic Regression Models of Situational Precipitators on Physical Force in Sexual Offenses controlling for the Risk of Apprehension, Context of Abuse and the Type of Offense

\begin{tabular}{|c|c|c|c|c|}
\hline Variable & $\begin{array}{l}\text { Model } 1 \\
\Psi \\
(95 \% \mathrm{CI}) \\
\end{array}$ & $\begin{array}{l}\text { Model } 2 \\
\Psi \\
(95 \% \mathrm{CI}) \\
\end{array}$ & $\begin{array}{l}\text { Model } 3 \\
\Psi \\
(95 \% \mathrm{CI}) \\
\end{array}$ & $\begin{array}{l}\text { Model } 4 \\
\Psi \\
(95 \% \mathrm{CI}) \\
\end{array}$ \\
\hline Used alcohol & $3.166^{* * *}$ & $3.157 * * *$ & $2.245 * * *$ & $2.259 * *$ \\
\hline before crime & $(1.96-5.12)$ & $(1.95-5.10)$ & $(1.28-3.94)$ & $(1.29-3.97)$ \\
\hline Used drugs & 1.427 & 1.398 & .981 & .983 \\
\hline before crime & $(.83-2.46)$ & $(.81-2.41)$ & $(.51-1.88)$ & $(.51-1.89)$ \\
\hline Used & .712 & .717 & .900 & .905 \\
\hline $\begin{array}{l}\text { pornography } \\
\text { before crime }\end{array}$ & $(.37-1.36)$ & $(.37-1.37)$ & $(.43-1.87)$ & $(.44-1.88)$ \\
\hline Had deviant & $.243 * * *$ & $.243 * * *$ & $.325 * *$ & $.337 *$ \\
\hline $\begin{array}{l}\text { sexual fantasies } \\
\text { towards the } \\
\text { victim } 48 \text { hours } \\
\text { before crime }\end{array}$ & $(.12-.51)$ & $(.12-.51)$ & $(.14-.76)$ & $(.14-.80)$ \\
\hline $\begin{array}{l}\text { Had nonspecific } \\
\text { deviant sexual } \\
\text { fantasies before } \\
\text { crime }\end{array}$ & $\begin{array}{l}5.199 * * * \\
(2.41-11.24)\end{array}$ & $\begin{array}{l}5.097 * * * \\
(2.35-11.05)\end{array}$ & $\begin{array}{l}6.601 * * * \\
(2.64-16.49)\end{array}$ & $\begin{array}{l}6.326 * * * \\
(.25-16.04)\end{array}$ \\
\hline $\begin{array}{l}\text { Was sexually } \\
\text { excited before } \\
\text { crime }\end{array}$ & $\begin{array}{l}.200 * * * \\
(.10-.42)\end{array}$ & $\begin{array}{l}.198 * * * \\
(.10-.41)\end{array}$ & $\begin{array}{l}.210 * * * \\
(.09-.49)\end{array}$ & $\begin{array}{l}.209 * * * \\
(.09-.49)\end{array}$ \\
\hline $\begin{array}{l}\text { Risk of } \\
\text { apprehension } \\
\text { was high before } \\
\text { crime }\end{array}$ & - & $\begin{array}{l}1.221 \\
(.79-1.92)\end{array}$ & $\begin{array}{l}.834 \\
(.487-1.43)\end{array}$ & $\begin{array}{l}.807 \\
(.46-1.41)\end{array}$ \\
\hline Type of offense & - & - & $* * *$ & $* * *$ \\
\hline $\begin{array}{l}\text { Adolescent } \\
\text { victim }\end{array}$ & - & - & $\begin{array}{l}3.06 * * * \\
(1.6-5.86)\end{array}$ & $\begin{array}{l}3.006^{* * * *} \\
(1.56-5.78)\end{array}$ \\
\hline Adult victim & - & - & $\begin{array}{l}21.89 * * * \\
(10.78-44.47)\end{array}$ & $\begin{array}{l}20.996 * * * \\
(10.16-43.41)\end{array}$ \\
\hline $\begin{array}{l}\text { Was a non } \\
\text { stranger }\end{array}$ & - & - & - & $\begin{array}{l}.804 \\
(.329-1.96)\end{array}$ \\
\hline Constant & 1.038 & .971 & $.392 * * *$ & .487 \\
\hline Nagelkerke $\mathrm{R}^{2}$ & .268 & .270 & .503 & .503 \\
\hline
\end{tabular}

Abbreviations: $\Psi=$ Odds ratio, $\mathrm{CI}=$ Confidence Intervals.

Note: $* p \leq .05, * * p \leq .01, * * * p \leq .001$. As a result of missing values, 420 cases were used. 
Table 4. Logistic Regression Models of Situational Precipitators on Penetration in Sexual Offenses controlling for the Risk of Apprehension, Context of Abuse and the Type of Offense

\begin{tabular}{|c|c|c|c|c|}
\hline Variable & $\begin{array}{l}\text { Model } 1 \\
\Psi \\
(95 \% \mathrm{CI}) \\
\end{array}$ & $\begin{array}{l}\text { Model } 2 \\
\Psi \\
(95 \% \mathrm{CI}) \\
\end{array}$ & $\begin{array}{l}\text { Model } 3 \\
\Psi \\
(95 \% \mathrm{CI}) \\
\end{array}$ & $\begin{array}{l}\text { Model } 4 \\
\Psi \\
(95 \% \mathrm{CI}) \\
\end{array}$ \\
\hline Used alcohol & $1.838 *$ & $1.839 *$ & 1.479 & 1.433 \\
\hline before crime & $(1.13-3.00)$ & $(1.13-3.01)$ & $(.89-2.47)$ & $(.86-2.40)$ \\
\hline Used drugs & 1.340 & 1.375 & 1.145 & 1.131 \\
\hline before crime & $(.77-2.34)$ & $(.79-2.41)$ & $(.642-2.04)$ & $(.63-2.02)$ \\
\hline Used & $.487^{*}$ & $.484 *$ & $.500 *$ & $.491 *$ \\
\hline $\begin{array}{l}\text { pornography } \\
\text { before crime }\end{array}$ & $(.27-.89)$ & $(.27-.88)$ & $(.27-.93)$ & $(.27-.91)$ \\
\hline Had deviant & 1.277 & 1.251 & 1.707 & 1.512 \\
\hline $\begin{array}{l}\text { sexual fantasies } \\
\text { towards the } \\
\text { victim } 48 \text { hours } \\
\text { before crime }\end{array}$ & $(.69-2.37)$ & $(.67-2.32)$ & $(.89-3.29)$ & $(.78-2.94)$ \\
\hline $\begin{array}{l}\text { Had nonspecific } \\
\text { deviant sexual } \\
\text { fantasies before } \\
\text { crime }\end{array}$ & $\begin{array}{l}.436 * * \\
(.23-.82)\end{array}$ & $\begin{array}{l}.449 * \\
(.24-.85)\end{array}$ & $\begin{array}{l}.397 * * \\
(.21-.77)\end{array}$ & $\begin{array}{l}.460 * \\
(.24-.90)\end{array}$ \\
\hline $\begin{array}{l}\text { Was sexually } \\
\text { excited before } \\
\text { crime }\end{array}$ & $\begin{array}{l}1.198 \\
(.61-2.34)\end{array}$ & $\begin{array}{l}1.206 \\
(.62-2.35)\end{array}$ & $\begin{array}{l}1.41 \\
(.71-2.82)\end{array}$ & $\begin{array}{l}1.461 \\
(.73-2.92)\end{array}$ \\
\hline $\begin{array}{l}\text { Risk of } \\
\text { apprehension } \\
\text { before crime was } \\
\text { high }\end{array}$ & - & $\begin{array}{l}.807 \\
(.51-1.28)\end{array}$ & $\begin{array}{l}.672 \\
(.42-1.08)\end{array}$ & $\begin{array}{l}.761 \\
(.46-1.25)\end{array}$ \\
\hline Type of offense & - & - & $* * *$ & $* * *$ \\
\hline $\begin{array}{l}\text { Adolescent } \\
\text { victim }\end{array}$ & - & - & $\begin{array}{l}2.19^{*} \\
(1.12-4.28)\end{array}$ & $\begin{array}{l}2.352 * \\
(1.2-4.63)\end{array}$ \\
\hline Adult victim & - & - & $\begin{array}{l}3.49 * * * \\
(1.95-6.24)\end{array}$ & $\begin{array}{l}4.344 * * * \\
(2.29-8.26)\end{array}$ \\
\hline $\begin{array}{l}\text { Was a non } \\
\text { stranger }\end{array}$ & - & - & - & $\begin{array}{l}2.053 \\
(.99-4.26)\end{array}$ \\
\hline Constant & $2.156^{* * *}$ & $2.319 * * *$ & $1.55^{*}$ & .761 \\
\hline Nagelkerke $\mathrm{R}^{2}$ & .080 & .083 & .147 & .159 \\
\hline
\end{tabular}

Abbreviations: $\Psi=$ Odds ratio, $\mathrm{CI}=$ Confidence Intervals.

Note: ${ }^{*} p \leq .05, * * p \leq .01, * * * p \leq .001$. As a result of missing values, 420 cases were used. 
Table 5. Logistic Regression Models of Situational Precipitators on Physical Injuries in Sexual Offenses controlling for the Risk of Apprehension, Context of Abuse and the Type of Offense

\begin{tabular}{|c|c|c|c|c|}
\hline Variable & $\begin{array}{l}\text { Model } 1 \\
\Psi \\
(95 \% \mathrm{CI}) \\
\end{array}$ & $\begin{array}{l}\text { Model } 2 \\
\Psi \\
(95 \% \mathrm{CI}) \\
\end{array}$ & $\begin{array}{l}\text { Model } 3 \\
\Psi \\
(95 \% \mathrm{CI}) \\
\end{array}$ & $\begin{array}{l}\text { Model } 4 \\
\Psi \\
(95 \% \mathrm{CI}) \\
\end{array}$ \\
\hline Used alcohol & $2.955 * * *$ & $3.026^{* * *}$ & $2.019 * *$ & $2.086^{*}$ \\
\hline before crime & $(1.79-4.89)$ & $(1.82-5.04)$ & $(1.13-3.6)$ & $(1.16-3.74)$ \\
\hline Used drugs & $1.872 *$ & $1.769 *$ & 1.64 & 1.651 \\
\hline before crime & $(1.11-3.16)$ & $(1.04-3.01)$ & $(.89-3.02)$ & $(.89-3.05)$ \\
\hline Used & $.420^{*}$ & $.411 *$ & .522 & .520 \\
\hline $\begin{array}{l}\text { pornography } \\
\text { before crime }\end{array}$ & $(1.18-.99)$ & $(.17-.98)$ & $(.20-1.38)$ & $(.20-1.39)$ \\
\hline Had deviant & $.320 * *$ & $.325^{* *}$ & .587 & 687 \\
\hline $\begin{array}{l}\text { sexual fantasies } \\
\text { towards the } \\
\text { victim } 48 \text { hours } \\
\text { before crime }\end{array}$ & $(.14-.73)$ & $(.14-.74)$ & $(.24-1.44)$ & $(.28-1.72)$ \\
\hline $\begin{array}{l}\text { Had nonspecific } \\
\text { deviant sexual } \\
\text { fantasies before } \\
\text { crime }\end{array}$ & $\begin{array}{l}2.034 \\
(.93-4.45)\end{array}$ & $\begin{array}{l}1.929 \\
(.88-4.21)\end{array}$ & $\begin{array}{l}1.364 \\
(.58-3.2)\end{array}$ & $\begin{array}{l}1.157 \\
(.48-2.79)\end{array}$ \\
\hline $\begin{array}{l}\text { Was sexually } \\
\text { excited before } \\
\text { crime }\end{array}$ & $\begin{array}{l}.138 * * \\
(.04-.47)\end{array}$ & $\begin{array}{l}.131 * * * \\
(.04-.46)\end{array}$ & $\begin{array}{l}.153^{* *} \\
(.04-.58)\end{array}$ & $\begin{array}{l}.147 * * \\
(.04-.56)\end{array}$ \\
\hline $\begin{array}{l}\text { Risk of } \\
\text { apprehension } \\
\text { was high before } \\
\text { crime }\end{array}$ & - & $\begin{array}{l}1.843 * \\
(1.14-2.99)\end{array}$ & $\begin{array}{l}1.226 \\
(.70-2.14)\end{array}$ & $\begin{array}{l}1.062 \\
(.59-1.93)\end{array}$ \\
\hline Type of offense & - & - & $* * *$ & $* * *$ \\
\hline $\begin{array}{l}\text { Adolescent } \\
\text { victim }\end{array}$ & - & - & $\begin{array}{l}1.24 \\
(.45-3.41)\end{array}$ & $\begin{array}{l}1.188 \\
(.43-3.28)\end{array}$ \\
\hline Adult victim & - & - & $\begin{array}{l}11.97 * * * \\
(6.05-23.79)\end{array}$ & $\begin{array}{l}10.840 * * * \\
(5.39-21.81)\end{array}$ \\
\hline $\begin{array}{l}\text { Was a non } \\
\text { stranger }\end{array}$ & - & - & - & $\begin{array}{l}.588 \\
(.28-1.22)\end{array}$ \\
\hline Constant & $.242 * * *$ & $.191 * * *$ & $.067 * * *$ & $.114^{* * *}$ \\
\hline Nagelkerke $\mathrm{R}^{2}$ & .227 & .245 & .450 & .454 \\
\hline
\end{tabular}

Abbreviations: $\Psi=$ Odds ratio, $\mathrm{CI}=$ Confidence Intervals.

Note: ${ }^{*} p \leq .05,{ }^{* *} p \leq .01, * * * p \leq .001$. As a result of missing values, 405 cases were used. 
Table 6. Logistic Regression Interaction Models on the Severity of Sexual Offenses

\begin{tabular}{|c|c|c|c|}
\hline Variable & Physical Force & Penetration & Physical Injuries \\
\hline & $\begin{array}{l}\text { Model } 1 \\
\Psi \\
(95 \% \mathrm{CI}) \\
\end{array}$ & $\begin{array}{l}\text { Model } 2 \\
\Psi \\
(95 \% \mathrm{CI}) \\
\end{array}$ & $\begin{array}{l}\text { Model } 3 \\
\Psi \\
(95 \% \mathrm{CI}) \\
\end{array}$ \\
\hline $\begin{array}{l}\text { Used alcohol before } \\
\text { crime }\end{array}$ & $\begin{array}{l}2.325 * * \\
(1.31-4.12)\end{array}$ & $\begin{array}{l}1.361 \\
(.81-2.29)\end{array}$ & $\begin{array}{l}2.040^{*} \\
(1.13-3.67)\end{array}$ \\
\hline Used drugs before crime & $\begin{array}{l}.990 \\
(.51-1.92)\end{array}$ & $\begin{array}{l}1.092 \\
(.61-1.97)\end{array}$ & $\begin{array}{l}1.588 \\
(.86-2.94)\end{array}$ \\
\hline $\begin{array}{l}\text { Used pornography } \\
\text { before crime }\end{array}$ & $\begin{array}{l}.980 \\
(.46-2.08)\end{array}$ & $\begin{array}{l}.541 \\
(.29-1.02)\end{array}$ & $\begin{array}{l}.518 \\
(.19-1.38)\end{array}$ \\
\hline $\begin{array}{l}\text { Had deviant sexual } \\
\text { fantasies towards the } \\
\text { victim before crime }\end{array}$ & $\begin{array}{l}.379 * \\
(.16-.91)\end{array}$ & $\begin{array}{l}1.462 \\
(.74-2.88)\end{array}$ & $\begin{array}{l}.716 \\
(.28-1.81)\end{array}$ \\
\hline $\begin{array}{l}\text { Had nonspecific deviant } \\
\text { sexual fantasies before } \\
\text { crime }\end{array}$ & $\begin{array}{l}5.469 * * * \\
(1.94-15.41)\end{array}$ & $\begin{array}{l}.781 \\
(.34-1.81)\end{array}$ & $\begin{array}{l}1.460 \\
(.469-4.54)\end{array}$ \\
\hline $\begin{array}{l}\text { Was sexually excited } \\
\text { before crime }\end{array}$ & $\begin{array}{l}2.605 \\
(.22-30.59)\end{array}$ & $\begin{array}{l}2.554 \\
(.36-18.18)\end{array}$ & $\begin{array}{l}.396 \\
(.045-3.46)\end{array}$ \\
\hline $\begin{array}{l}\text { Perceived high risk of } \\
\text { apprehension before } \\
\text { crime }\end{array}$ & $\begin{array}{l}.810 \\
(.42-1.55)\end{array}$ & $\begin{array}{l}1.081 \\
(.61-1.94)\end{array}$ & $\begin{array}{l}1.220 \\
(.626-2.38)\end{array}$ \\
\hline Was a non stranger & $\begin{array}{l}1.241 \\
(.49-3.15)\end{array}$ & $\begin{array}{l}2.042 \\
(.94-4.45)\end{array}$ & $\begin{array}{l}.615 \\
(.29-1.30)\end{array}$ \\
\hline Type of offense & $* * *$ & $* * *$ & $* * *$ \\
\hline Adolescent victim & $\begin{array}{l}2.812 * * \\
(1.46-5.44)\end{array}$ & $\begin{array}{l}2.336^{*} \\
(1.18-4.62)\end{array}$ & $\begin{array}{l}1.186 \\
(.43-3.29)\end{array}$ \\
\hline Adult victim & $\begin{array}{l}24.228 * * * \\
(11.30-51.98)\end{array}$ & $\begin{array}{l}4.722 * * * \\
(2.45-9.12)\end{array}$ & $\begin{array}{l}11.415 * * * \\
(5.62-23.18)\end{array}$ \\
\hline $\begin{array}{l}\text { Was sexually excited } \\
\text { before crime X Was a } \\
\text { non stranger }\end{array}$ & $\begin{array}{l}.048^{*} \\
(.003-.71)\end{array}$ & $\begin{array}{l}.538 \\
(.07-4.46)\end{array}$ & $\begin{array}{l}.203 \\
(.01-4.14)\end{array}$ \\
\hline $\begin{array}{l}\text { Risk of apprehension } \\
\text { was high X Had } \\
\text { nonspecific deviant } \\
\text { sexual fantasies before } \\
\text { crime }\end{array}$ & $\begin{array}{l}1.115 \\
(.32-3.90)\end{array}$ & $\begin{array}{l}.275^{*} \\
(.09-.81)\end{array}$ & $\begin{array}{l}.534 \\
(.15-1.96)\end{array}$ \\
\hline Constant & $.317^{*}$ & .676 & $.104^{* * *}$ \\
\hline Nagelkerke $\mathrm{R}^{2}$ & .515 & .177 & .459 \\
\hline
\end{tabular}

Abbreviations: $\Psi=$ Odds ratio, $\mathrm{CI}=$ Confidence Intervals.

Note: ${ }^{*} p \leq .05, * * p \leq .01, * * * p \leq .001$. 